\title{
PHYSICAL, CHEMICAL, AND BIOLOGICAL DATA FOR FOUR WETLAND HABITATS IN CANAAN VALLEY, WEST VIRGINIA
}

By Douglas B. Chambers

U.S. GEOLOGICAL SURVEY

Open-File Report 95-334

Prepared in cooperation with the

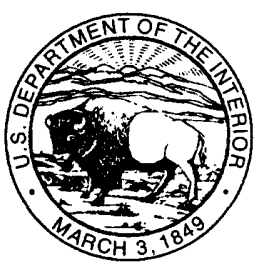

WEST VIRGINIA DIVISION OF ENVIRONMENTAL PROTECTION 


\section{U.S. DEPARTMENT OF THE INTERIOR \\ BRUCE BABBITT, Secretary \\ U.S. GEOLOGICAL SURVEY \\ Gordon P. Eaton, Director}

For additional information write to:

District Chief U.S. Geological Survey 11 Dunbar Street

Charleston, West Virginia 25301
Copies of this report can be purchased from:

U.S. Geological Survey Branch of Information Services Box 25286

Denver, CO 80225-0286 


\section{CONTENTS}

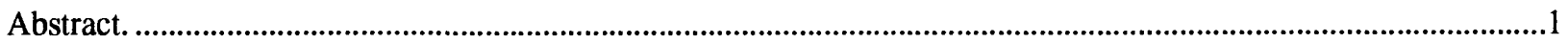

Introduction.

Purpose and scope

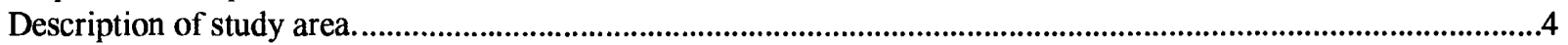

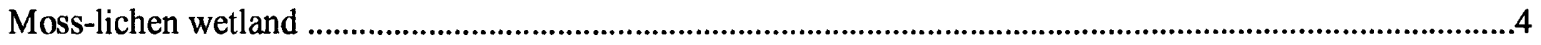

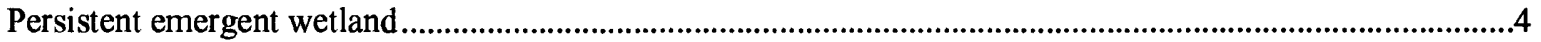

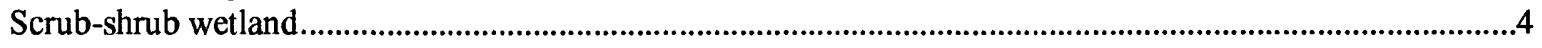

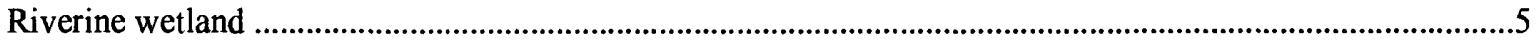

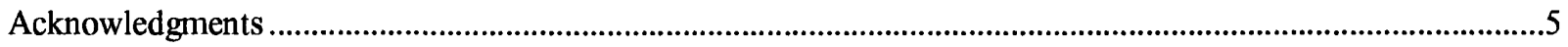

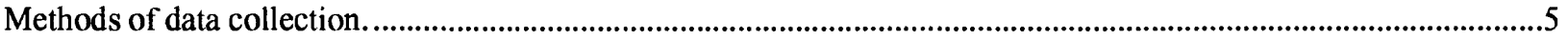

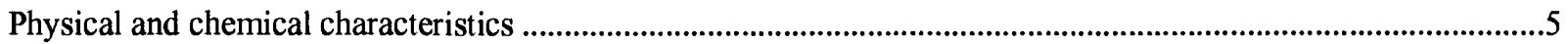

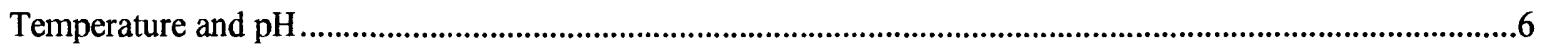

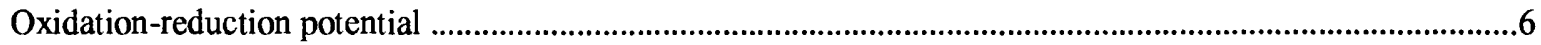

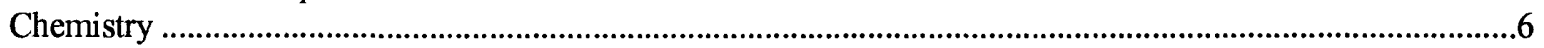

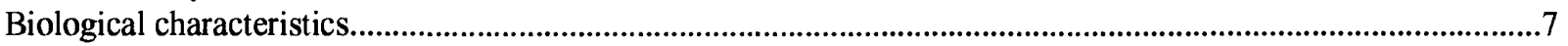

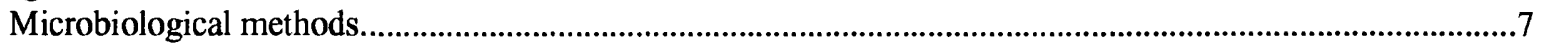

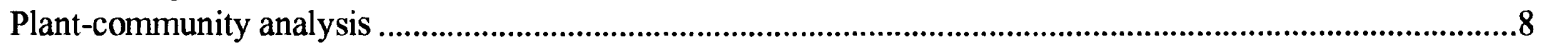

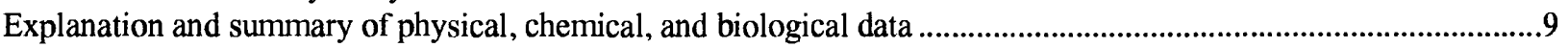

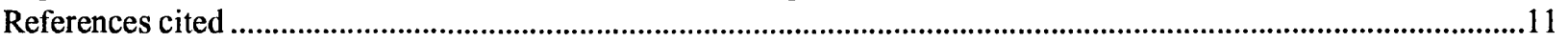

\section{FIGURES}

1. Map showing location of denitrification study area in Canaan Valley, West Virginia, with wetland habitat types identified

2. Schematic diagram of core sample tubes, showing solid tube and tube with

$\mathrm{pH}$ and temperature ports

3a-e. Graphs of selected characteristics for four wetland habitats in Canaan Valley:

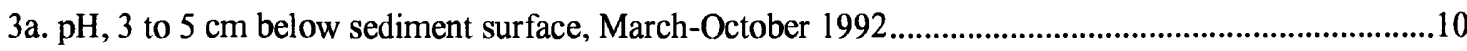

3b. Organic carbon in bottom material, March-October 1992 .....................................................................10

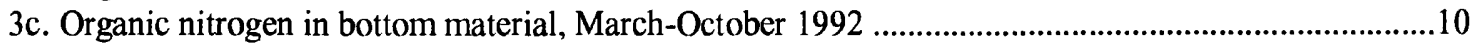

3d. Ammonia nitrogen in bottom material, March-October 1992 .............................................................10

3e. Most probable number of denitrifying bacteria per gram of wet soil, March-October 1992 ................10 


\section{TABLES}

1. Physical and chemical characteristics and most probable number of denitrifying bacteria per gram wet weight of soil for a moss-lichen wetland in Canaan Valley, March-October 1992.

2. Physical and chemical characteristics and most probable number of denitrifying bacteria per gram wet weight of soil for a persistent emergent wetland in Canaan Valley, March-October 1992

3. Physical and chemical characteristics and most probable number of denitrifying bacteria per gram wet weight of soil for a scrub-shrub wetland in Canaan Valley, March-October 1992

4. Physical and chemical characteristics and most probable number of denitrifying bacteria per gram wet weight of soil for a riverine wetland in Canaan Valley, March-October 1992.

5. Importance value and frequency for dominant plant species in three wetland habitats in Canaan Valley, 1992 .18 


\title{
Physical, Chemical, and Biological Data for Four Wetland Habitats in Canaan Valley, West Virginia
}

\author{
By Douglas B. Chambers
}

\section{ABSTRACT}

This report contains data collected during 1992 as part of a project designed to identify microenvironmental factors affecting rates of denitrification in wetlands in Canaan Valley, W. Va. Four wetland habitats were selected for the study: a moss-lichen wetland, a persistent emergent wetland, a scrubshrub wetland, and a riverine wetland. Physical, chemical, and biological characteristics of each habitat were determined by field measurements and laboratory analyses. Samples were collected from the four wetland habitats in March, June, August, and October. Sediment $\mathrm{pH}$, temperature, and oxidation-reduction potential were measured in the field. Sediment samples were analyzed for concentrations of calcium, sodium, magnesium, potassium, nitrate and nitrite, ammonia, ammonia plus organic nitrogen, phosphorus, inorganic carbon, and total carbon. The most probable number of denitrifying bacteria was determined by a multiple-tube test. The dominant plant species were identified by plant-community analysis. The mosslichen wetland was characterized by low $\mathrm{pH}$ ( 3.4 to 5.0) and small populations of denitrifying bacteria (70 to 400 per gram of wet soil). The scrub-shrub wetland was also acidic ( $\mathrm{pH} 4.0$ to 5.0), but supported larger numbers of denitrifying bacteria ( 510 to 11,000 per gram of wet soil). The number of denitrifying bacteria in the persistent emergent wetland exceeded $1,000,000$ per gram of wet soil in early summer and $\mathrm{pH}$ in this habitat was higher (5.1 to 6.6) than in the bogs. Riverine wetland $\mathrm{pH}$ ranged from 5.4 to 6.9 , and the number of denitrifying bacteria ranged from 200 to 11,000 per gram of wet soil.

\section{INTRODUCTION}

Wetlands can be either sources or sinks in the biogeochemical cycles of many elements. Studies conducted in both natural and constructed wetlands found that rheotrophic and minerotrophic wetlands are sinks for many wastewater constituents (Mitsch and Gosselink, 1986). Wetland treatment of wastewater discharges has resulted in significant reduction of suspended-solid concentrations, biochemical oxygen demand, and concentrations of nutrients such as phosphorus and nitrogen (Tchobanoglous and Schroeder, 1985). The ability of wetlands to remove nutrients is of interest because nutrient concentrations often remain high, even after secondary treatment of effluents by conventional means. Natural wetlands can remove nitrogen, a major wastewater component, by denitrification, a microbially-mediated biochemical process that reduces nitrate and nitrite to gaseous nitrogen. Studies of nitrogen budgets and cycling indicate that denitrification is a significant pathway for nitrogen removal from some aquatic ecosystems (Chen and others, 1972). In light of this information, constructed wetlands have been proposed as a way to provide wastewater treatment for communities that do not have conventional treatment facilities (Jewell, 1994). Many communities in the central Appalachians, a region that experiences severe winters, lack sufficient wastewater treatment facilities, and would benefit from the use of alternate treatment technologies. It is not understood at present, however, which environmental conditions control denitrification in wetlands in regions similar to the central Appalachians. 
Denitrification is an adaptation to the anaerobic environments common in wetlands. In the absence of oxygen, several genera of facultatively anaerobic bacteria are able to use nitrate as the final electron acceptor of their electron transport chain. Nitrite produced by these species is excreted or, under appropriate conditions, reduced by hydroxylamine to ammonium. True denitrifying nitrate-reducers carry out a more complete reduction pathway, converting nitrite through nitric oxide to nitrous oxide and molecular nitrogen. These gaseous species are readily lost to the atmosphere by diffusion.

In many ecosystems, productivity is limited by the availability of mineralized nitrogen. Species requiring nitrogen for growth are often in competition for available nitrogen resources, and nitrate is usually taken up quickly and immobilized in biomass. However, nitrogen is relatively abundant in some eutrophic wetland habitats, and does not significantly limit growth (Mitsch and Gosselink, 1986). It is in these habitats, where abundant nitrogen and anaerobic environments both occur, that denitrification is an important part of the local nitrogen cycle. Studies by Keeney and others (1971) indicated that 63 percent of the nitratenitrogen entering Lake Mendota sediments by ground-water seepage is removed by denitrification. Similarly, in a series of experiments in which nitrate-nitrogen was mixed into lake sediments and wetland soils, as much as 90 percent of the added nitrogen was removed within a few days by denitrification (Bartlett and others, 1979).

In addition to nitrogen availability and anaerobic environments, there are other microenvironmental factors that can affect denitrification in wetlands, such as temperature, $\mathrm{pH}$, oxidationreduction potential, and availability of organic carbon. Denitrification appears to be inhibited by low temperatures (Bremner and Shaw, 1958), and therefore temperate wetlands can be expected to exhibit seasonal fluctuations in rates of denitrification and in the relative importance of denitrification in the nitrogen mass balance (Mitsch and Gosselink, 1986).

Denitrification in wetlands may be dependent upon the rate of oxidation of ammonia to nitrate and on the relative locations of oxidizing and reducing microenvironments in the water-soil column (Patrick and Reddy, 1976). Reddy and Graetz (1988) suggest that the ultimate conversion of ammonium ion to nitrogen gas by nitrification and denitrification proceeds at a faster pace in wetland areas with rooted plants because the aerobic microzones associated with roots provide a shorter pathway for diffusion between aerobic and anaerobic soil environments (Howes and others, 1981).

Finally, Chen and others (1972) have suggested the rate of disappearance of nitrate from acidic sediments can result as much from the chemical breakdown of nitrite as from microbial production of gaseous nitrogen oxides. When $\mathrm{pH}$ is lower than 6 , microbial reduction of nitrous oxide is strongly inhibited (Wiljer and Delwiche, 1954). Below pH 5, the nitrite ion is unstable and will react spontaneously with amino acids, ammonia, and urea to form nitrogen gas. Organic soil matter seems to increase the instability of nitrite (Broadbent and Clark, 1965), indicating that this process can be especially significant in wetlands.

The specific combination of these microenvironmental conditions can affect the rate at which denitrification will proceed, and therefore the efficiency of nitrogen removal. Data related to the physical and chemical characteristics of wetlands are necessary to assess the feasibility of creating wetlands for wastewater treatment in the Appalachian Plateau and in other areas with similar climates.

The U.S. Geological Survey (USGS) cooperated with the West Virginia Department of Environmental Protection and the interagency Canaan Valley Task Force to identify environmental factors influencing rates of denitrification in Appalachian Plateau wetlands. The study was conducted at a site in Canaan Valley, Tucker County, West Virginia, where four distinct wetland habitats are found: a moss-lichen wetland, a persistent emergent wetland, a scrub-shrub wetland, and a riverine wetland along the Blackwater River (fig. 1). These four habitats are located close to one another, but include a wide range of microenvironmental characteristics. This facilitates comparison of differences among habitat types arising from microenvironmental factors, while eliminating the need to consider macroenvironmental factors, such 

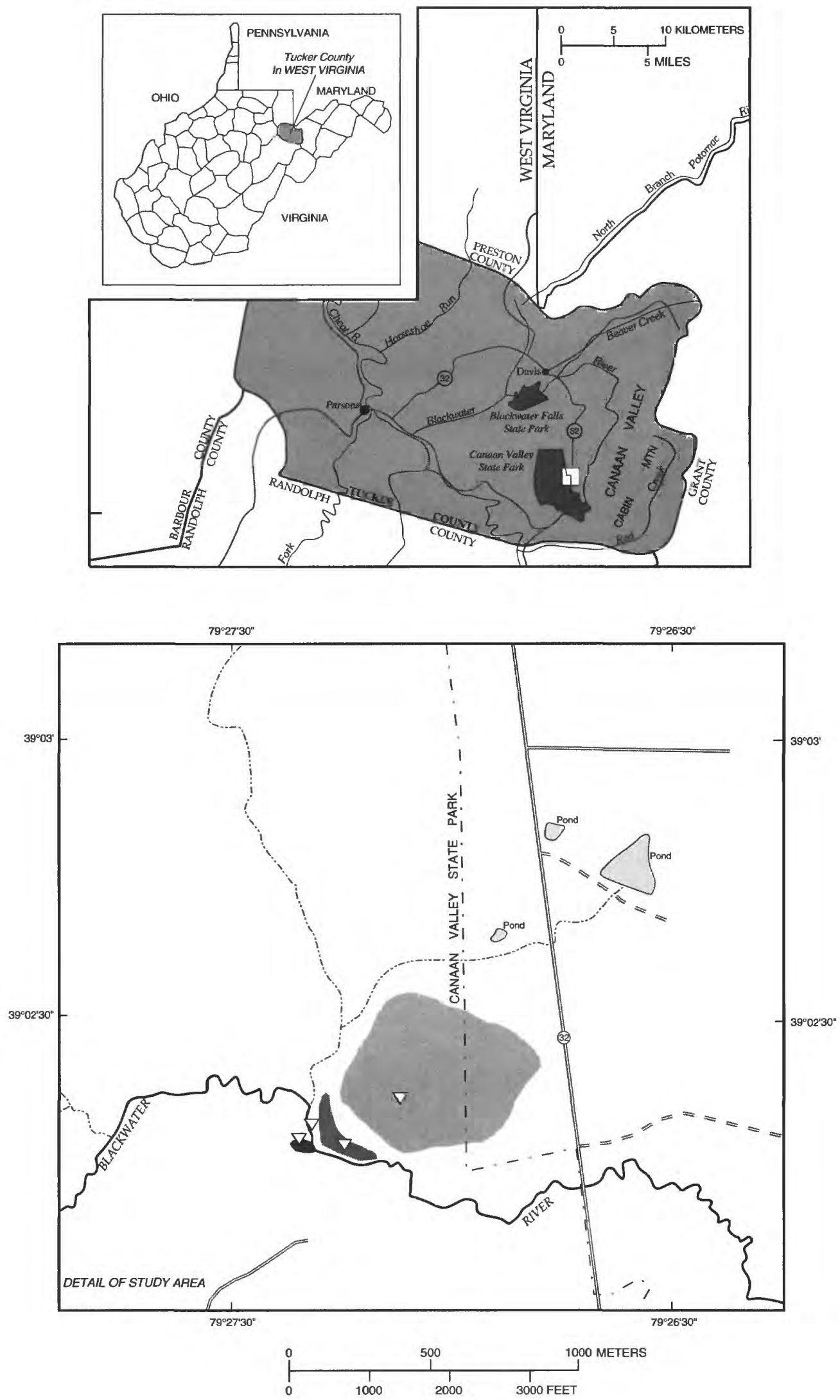

\section{EXPLANATION}

MOSS - LICHEN WETLAND

- PERSISTENT EMERGENT WETLAND

SCRUB - SHRUB WETLAND

$\nabla$ SAMPLING STATION

- - PARK BOUNDARY

Figure 1. Location of denitrification study area in Canaan Valley, West Virginia, with wetland habitat types identified. 
as climate. Data were collected to provide information pertaining to seasonal changes in the numbers of denitrifying bacteria and chemical characteristics of sediments from the four wetland habitats.

\section{Purpose and Scope}

This report presents physical, chemical, and microbiological data collected in four distinct wetland habitats in Canaan Valley, West Virginia, from March to October 1992. Samples were collected for analysis and characteristics were measured at four sites. Descriptions of the methods used to collect and analyze samples are included. Data for $\mathrm{pH}$, reduction-oxidation potential, temperature, and selected chemical and biological characteristics are given in tables 1 to 5 (at end of report).

\section{Description of Study Area}

The study area is in Canaan Valley State Park which is located in the southern end of Canaan Valley, Tucker County, W. Va. Canaan Valley is a breached anticline that is approximately $23 \mathrm{~km}$ long and averages about $6 \mathrm{~km}$ wide. The valley floor has an average elevation of 975 meters, and surrounding mountains rise as high as $300 \mathrm{~m}$ above the valley floor. The valley is drained by the Blackwater River. A central ridge of low rolling hills separates the two branches of the Blackwater River in the southern half of the valley. Lowlands surrounding this ridge include wet meadows, beaver pond wetlands, and peat bogs. This complex is the largest wetland system in West Virginia (Workman, 1988).

The study area consists of four wetland habitats in the southern part of the valley--a mosslichen wetland, a persistent-emergent wetland, an scrub-shrub wetland and a riverine wetland. The moss-lichen, persistent-emergent, and scrub-shrub wetlands are adjacent to the Blackwater River and the riverine wetland is along the river's main channel (fig. 1). The study area is approximately $1.3 \mathrm{~km}$ downstream from the origin of the Blackwater River at the confluence of Club Run and Mill Run. The Blackwater River meanders through a series of marshes and beaver ponds. The scrub-shrub and moss-lichen wetland sites are north of this area. The persistent-emergent wetland site is located in a small backwater of the Blackwater River. The riverine wetland site is located in the main channel of the Blackwater River near the marshy peninsula between the river and the backwater.

\section{Moss-Lichen Wetland}

The moss-lichen wetland is a poorly drained area dominated by hummocks of sphagnum and hair-cap (Polytrichum spp.) mosses interspersed with sedges (Carex spp.). The hummocks are often surrounded by standing water, and the water table is at or near the land surface for much of the year (Michael and Pauley, 1988). A shallow layer of impermeable clay underlaying the wetland maintains the water table in the wetland. The saturated conditions in the bogs create an anaerobic environment with a reduced rate of decomposition, conditions that lead to an accumulation of as much as 1.2 $m$ of peat in the bogs (Cameron, 1970). The low decomposition rates slow the mineralization of organic nitrogen to inorganic forms that are available for uptake by plants.

\section{Persistent Emergent Wetland}

The persistent emergent wetland is a wetmeadow marsh located in a backwater of the Blackwater River. The marsh, which typically remains flooded during most of the year, is dominated by grasses (Calamagrostis, Glyceria) and sedges (Carex stricta, C. folliculata) (Fortney, 1975; Michael and Pauley, 1988). The presence of rooted macrophytes can create aerobic microzones in what would otherwise be anaerobic sediments. The backwater is inundated by the Blackwater River and also receives discharge from a small spring located along the marsh's southern edge.

\section{Scrub-Shrub Wetland}

The scrub-shrub wetland is located in a transitional zone between the moss-lichen wetland and the Blackwater River. The area is separated from the river by a layer of clay found in the riverbank. The soil is poorly drained and consists primarily of 
peat similar to that found in the adjacent mossdominated bog. The peat is less saturated with water than in the adjacent moss-lichen wetland, so that the area has been colonized, and now dominated, by alders (Alnus rugosa), a shrub or small tree, and spiraea (Spiraea alba), a shrub. Alder trees are often early pioneers in nitrogen poor habitats due to their ability to symbiotically fix atmospheric nitrogen.

\section{Riverine Wetland}

The riverine wetland site is located in the Blackwater River, adjacent to the wet-meadow marsh. This site supports no macrophyte growth, although dense beds of Spirogyra, a green alga, grow on the streambed during low-flow periods.

\section{Acknowledgments}

The author wishes to thank the West Virginia Department of Environmental Protection and the Canaan Valley Task Force for their support of this investigation, and Dr. Ronald H. Fortney of SalemTeikyo University for conducting the plant-community analysis and advice in selecting sampling locations.

\section{METHODS OF DATA COLLECTION}

Data presented in this report consist of physical, chemical, and microbiological analyses done in the field and in the laboratory. Data were derived from analysis of sediment samples collected by USGS personnel. Sediment samples were collected from each of the four wetland habitats in spring, early summer, late summer, and fall. Sampling began on March 21, 1992. Data collected during that trip were used to develop the protocols for subsequent trips on June 11 to 12 , August 11 to 14, and October 21 to $23,1992$.

All samples were collected with a Wildco ${ }^{1}$ hand corer using cellulose acetyl-butyrate liner

1. The use of brand, firm, or trade name in this report is for identification purposes and does not constitute endorsement by the U. S. Geological Survey. tubes that were 30 by $5 \mathrm{~cm}$ in diameter (fig. 2). Three samples were taken from each habitat during each sampling trip--one sample to measure field characteristics, one to analyze chemical composition, and one to determine the most probable number of denitrifying bacteria. A sample was collected by pushing the hand corer 20 to $25 \mathrm{~cm}$ below the surface of the wetland sediment. The corer was then slowly pulled out, trapping a relatively undisturbed profile of the sediment in the corer's liner tube. The liner tube was removed from the corer, capped, and sealed. Core-sample field characteristics were analyzed immediately. Other core samples were transported on ice to Charleston, W. Va., for microbiological or chemical analysis.

\section{Physical and Chemical Characteristics}

Vertical profiles of sediment $\mathrm{pH}$, oxidationreduction (redox) potential, and temperature were measured in the field. Concentrations of 10 chemi-
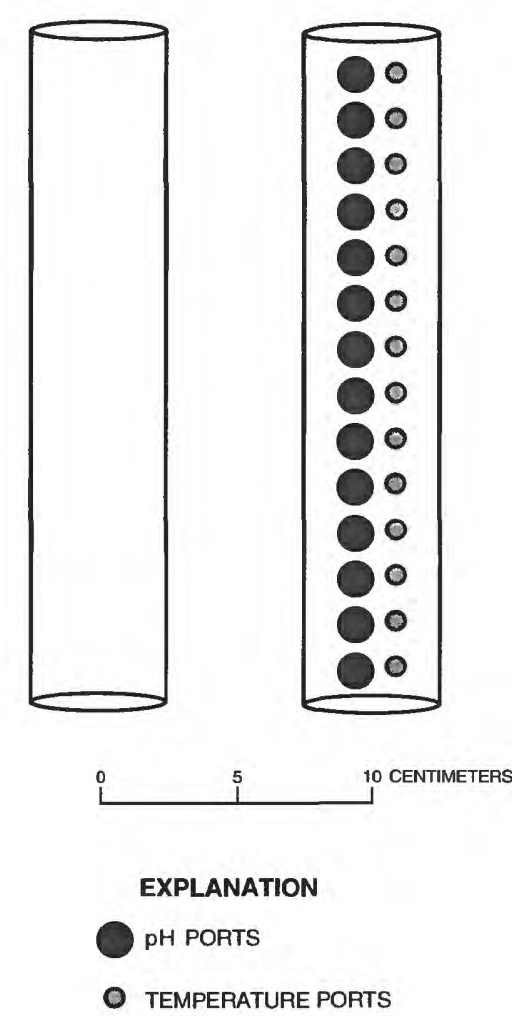

Figure 2. Core sample tubes, showing solid tube and tube with $\mathrm{pH}$ and temperature ports. 
cal constituents in sediments were determined by the U.S. Geological Survey's National Water Quality Laboratory (NWQL) in Arvada, Colo.

Sediment $\mathrm{pH}$, redox potential, and temperature were measured in the field. Cores for these measurements were collected in liner tubes with two sampling ports drilled every $2 \mathrm{~cm}$. These ports were closed with plastic tape to prevent the loss of interstitial water before measurement. Measurements were made within 15 minutes after the sample was collected, by removing the tape from the sample port and inserting probes into the sediments. A measurement was made every $2 \mathrm{~cm}$, starting 1 to $2 \mathrm{~cm}$ below the sediment surface. All probes were used with an Orion model $250 \mathrm{~A}$ portable $\mathrm{pH} / \mathrm{ISE}$ meter.

\section{Temperature and $\mathrm{pH}$}

Temperature and $\mathrm{pH}$ were measured simultaneously by inserting an Orion triode $\mathrm{pH}$ electrode into the center of the core sample. Sediment temperatures were measured with either a combination thermistor/pH probe, or by inserting a separate thermistor and $\mathrm{pH}$ probe into each of the two sampling ports. The electrode and meter were calibrated according to the manufacturer's instructions before measuring each vertical profile, and checked against $\mathrm{pH} 7$ and $\mathrm{pH} 4$ standards upon completion of each vertical profile.

\section{Oxidation-Reduction Potential}

The oxidation-reduction potential of the sediment was measured with a Lazar ORP-146COMB probe connected to an Orion model 250A portable $\mathrm{pH} / \mathrm{ISE}$ meter programmed to read millivolts. The probe tip was dipped in $5 \mathrm{~N}$ nitric acid for $30 \mathrm{sec}-$ onds and rinsed with deionized water before being measured. Measurements were recorded after the readings stabilized. Meter accuracy was checked against solutions of known redox potential. Solutions of $\mathrm{pH} 4$ and $\mathrm{pH} 7$ buffer, amended with $6 \mathrm{~g} / \mathrm{L}$ of quinhydrone, were used, which at $25^{\circ} \mathrm{C}$ have redox values of 285 millivolts and 465 millivolts, respectively (Hydrolab, 1991).

\section{Chemistry}

Sediment samples were analyzed by the NWQL for concentrations of calcium, magnesium, potassium, sodium, nitrogen (as nitrite plus nitrate, as ammonia, and as ammonia plus organic species), phosphorus, inorganic plus organic carbon, and inorganic carbon. Samples were collected in acid-washed liner tubes. A sample of approximately $20 \mathrm{~cm}$ of sediment and 2 to $3 \mathrm{~cm}$ of any overlying water was collected from each site. The sample was immediately sealed and placed on ice for transport to the West Virginia District laboratory in Charleston, where it was processed within 24 hours. Any overlying water was poured off, the top $15 \mathrm{~cm}$ of the sediment core extruded from the liner tube, and the top $10 \mathrm{~cm}$ of each sample was removed and pushed through a $2 \mathrm{~mm}$ mesh sieve. Samples were maintained at about $4^{\circ} \mathrm{C}$ to inhibit biological or chemical changes in composition. Approximately $100 \mathrm{~g}$ of the sieved sample was shipped on ice to NWQL for analysis.

At the NWQL, wetland sediments were analyzed by colorimetry, atomic absorption spectrophotometry, and thermal conductivity (Skougstad and others, 1979). Samples were prepared for atomic absorption spectrophotometry by removing organic and acid-soluble materials. The resulting solution was analyzed for calcium, magnesium, potassium, and sodium. Results of these analyses were reported as concentrations "recoverable from bottom material," defined as the amount of an analyte present in the sample extraction solution, which is usually less than 95 percent of the total amount of the constituent in the sample. Phosphorus and nitrogen species (nitrite plus nitrate, ammonia, and ammonia plus organic nitrogen) were determined by colorimetric methods. Values for these measurements are reported as "total in bottom material," meaning at least 95 percent of the constituent present in the sample has been measured. Organic plus inorganic carbon concentration was determined by oxidizing the sample and measuring the evolved carbon dioxide by thermal conductivity. Inorganic carbon was measured through a modified Van Slyke method, in which the sample is acidified, heated, and the resulting carbon dioxide is measured manometrically. Carbon-analysis values are reported as "total in bottom material." 


\section{Biological Characteristics}

Biological data reported consist of the most probable number of denitrifying bacteria and plantcommunity analysis. The most probable number (MPN) analysis uses multiple-tube tests to predict the most likely density of bacteria responsible for reducing nitrate to gaseous nitrogen. This analysis was conducted on sediment samples from each wetland habitat. Plant communities were analyzed along transects established in each habitat type. Plant-community analysis is the characterization of the vegetation of an area without a complete census of the area.

\section{Microbiological Methods}

Most probable number (MPN) analyses for denitrifying bacteria use multiple-tube tests to predict the most likely density of bacteria in a soil or water sample. The MPN method uses gas production and nitrate removal as indicators of the presence of denitrifiers (the bacteria responsible for the reduction of nitrate to gaseous nitrogen). The MPN for denitrifiers is determined by analyzing the distribution of positive results in a series of culture tubes inoculated with aliquots of sediment serially diluted by a factor of ten (Britton and Greeson, 1989).

Samples from the top $2 \mathrm{~cm}$ of each sediment core were extruded and aseptically transferred to sterile weighing pans. Ten grams of each sample was transferred to a dilution bottle containing 95 milliliters $(\mathrm{mL})$ of sterile water and 36 glass beads $3 \mathrm{~mm}$ in diameter. The dilution bottle was shaken for 1 minute, after which $10 \mathrm{~mL}$ of diluted sample was transferred to a dilution bottle containing 90 $\mathrm{mL}$ of sterile water. This bottle was shaken for 30 seconds. A $10-\mathrm{mL}$ aliquot of this dilution was transferred to another dilution bottle containing 90 $\mathrm{mL}$ of sterile water and shaken. This procedure was repeated until a final dilution of $10^{-6}$ was reached.

For each sample, 25 culture tubes were prepared with $9 \mathrm{~mL}$ of nutrient broth amended with 0.1 percent potassium nitrate $\left(\mathrm{KNO}_{3}\right)$ and an inverted Durham tube. Five tubes were each inoculated with $1 \mathrm{~mL}$ of each decimal dilution between $10^{-2}$ and $10^{-6}$, for a total of five dilutions. An additional set of 25 tubes was prepared and each inoculated with sterile water that had been passed through an identical series of dilutions. After inoculation, all tubes were sealed and incubated at $28^{\circ} \mathrm{C}\left( \pm 1^{\circ} \mathrm{C}\right)$ for 2 weeks.

Nitrogen gas production and removal of nitrate $\left(\mathrm{NO}_{3}{ }^{-}\right)$are positive indications of denitrification. Nitrogen gas production is determined by visual inspection. The test for nitrate removal requires the use of test reagents. The first reagent is clear and develops a deep red color in the presence of nitrite $\left(\mathrm{NO}_{2}{ }^{-}\right)$, an intermediate product of denitrification. The nitrite-test reagent is prepared by adding 100 $\mathrm{mL}$ of concentrated phosphoric acid and $10 \mathrm{~g}$ of sulfanilamide to $750 \mathrm{~mL}$ of deionized water (stirring and slight warming may be necessary to ensure complete dissolution). To this solution, 0.5 $\mathrm{g}$ of $\mathrm{n}$-1-naphthylenediamine dihydrochloride is added. The solution is further diluted with deionized water to a final volume of $1 \mathrm{~L}$, and refrigerated in amber glass bottles. Testing for nitrate requires adding approximately $50 \mathrm{mg}$ of a mixture of $1 \mathrm{~g}$ of powdered zinc, $1 \mathrm{~g}$ of powdered manganese dioxide, and $0.1 \mathrm{~g}$ of powdered copper. This mixture reduces $\mathrm{NO}_{3}{ }^{-}$to $\mathrm{NO}_{2}{ }^{-}$, which can be detected with the nitrite-test reagent.

At the end of the incubation period, each tube is examined for nitrogen gas $\left(\mathrm{N}_{2}\right)$ production and tested for $\mathrm{NO}_{3}{ }^{-}$and $\mathrm{NO}_{2}{ }^{-}$removal. The first step is a visual examination of the Durham tube for a gas bubble. If a gas bubble is present, it is presumed to be $\mathrm{N}_{2}$ and the tube is then tested for $\mathrm{NO}_{2}{ }^{-}$, which is detected by adding $0.5 \mathrm{~mL}$ of nitrite-test reagent. Tubes that show a red color are positive for $\mathrm{NO}_{2}{ }^{-}$. If $\mathrm{NO}_{2}^{-}$is not detected, or is present in such low concentrations as to yield a light pink color, the tube is tested for $\mathrm{NO}_{3}{ }^{-}$. Approximately $50 \mathrm{mg}$ of the zinc-copper-manganese dioxide mixture is added to each colorless or light pink tube. If any $\mathrm{NO}_{3}{ }^{-}$is present, it will react with the metal mixture to produce $\mathrm{NO}_{2}{ }^{-}$. This newly reduced $\mathrm{NO}_{2}{ }^{-}$will react with the nitrite-test reagent already in the tube to yield a color change. Therefore, a color change within 5 minutes of the addition of the metal mixture is a positive result for the presence of $\mathrm{NO}_{3}$. 
The results of the tests for $\mathrm{N}_{2}, \mathrm{NO}_{2}^{-}$, and $\mathrm{NO}_{3}{ }^{-}$ are used to determine if denitrification has occurred in the culture tube, thereby indicating the presence of denitrifying bacteria. Tubes that are positive for $\mathrm{N}_{2}$ production and negative for both $\mathrm{NO}_{2}{ }^{-}$and $\mathrm{NO}_{3}{ }^{-}$are considered a positive test for denitrification. Also, tubes positive for $\mathrm{N}_{2}$ and $\mathrm{NO}_{2}{ }^{-}$, but negative for $\mathrm{NO}_{3}{ }^{-}$, are recorded as positive denitrification test results. The first combination of results is indicative of the denitrification process carried through to completion, while the second combination indicates the incomplete reduction of available $\mathrm{NO}_{2}^{-}$. All other combinations of results are negative for denitrification (Britton and Greeson, 1989).

The MPN of denitrifying bacteria is calculated by comparing positive results per number of tubes per dilution for each sample with a MPN table (American Public Health Association and others, 1989 , p. 9-78). Although five dilutions were cultured to cover a wider range of concentrations, only three--the highest dilution that gave positive results for all five tubes, and the next two higher dilutions--were used for computing the MPN.

\section{Plant-Community Analysis}

Plant communities were analyzed in the mosslichen wetland, the persistent emergent wetland, and the scrub-shrub wetland. The riverine community lacks macrophytes and, therefore, was not analyzed. Several methods were used, chosen for the specific characteristics of the type of vegetation being sampled (Smith, 1990, Dr. Ronald H. Fortney, Salem-Teikyo University, written commun., 1994). A point-frequency intercept method was used in the moss-lichen wetland to sample the moss ground cover and creeping and low shrub strata. A line-intercept method was used for the shrub stratum and a line-point method was used for the ground, creeping, and herbaceous strata in the persistent emergent and the scrub-shrub wetlands. All plant communities were analyzed by $\mathrm{Dr}$. Ronald H. Fortney of Salem-Teikyo University, Salem, W. Va.

The point-frequency method, which was used in the moss-lichen wetland, samples the plant species found at a number of points. Two central points were located within the wetland, and four randomly located lines were established from these points. Point-pin frames were randomly located along each line. Point-pin frames hold as many as 10 wire pins perpendicular to the ground, where each pin represents a single point to be sampled. As the pins are lowered in the frame, each plant species that comes in contact with a pin is counted and recorded. Additionally, $0.5-\mathrm{m}^{2}$ quadrats (sampling plots) were established along the same lines and were used to sample herbaceous emergent plants by stem counts. This corrects the underrepresentation of these herbaceous species in the pin frame counts.

Line-intercept and line-point methods were used to characterize the persistent emergent and scrub-shrub wetland communities. Sampling in both habitats was conducted along parallel-line transects established every $33 \mathrm{~m}$. The shrub stratum was sampled with the line-intercept method, in which all plant canopies above the transect are tallied. The line-point method was used to sample vegetation at $0.5-\mathrm{m}$ intervals along the line transect for the ground, creeping, and herbaceous strata. Species in the ground, creeping, and herbaceous strata above or below a point were recorded.

Data were used to calculate the cover, frequency, relative frequency, density and relative density, and importance value (IV) for each species in a habitat. Cover is the percentage of sampled area below the canopy of a given species. Relative cover is the contribution of the species to total cover, expressed as a percentage. Frequency is the percentage of quadrats or sampling points that include at least one individual of a species. Relative frequency is the frequency of a species as a percentage of total plant frequency. Density is the total number of plants tallied at each sampling location, and relative density is the density of a species, expressed as a percentage of total density (Barbour and others, 1987). IV is the sum of the more significant characteristics of a particular community or stratum. For shrubs, IV is the sum of relative cover, relative frequency, and relative density. Therefore, the maximum possible IV for the shrub stratum is 300 . For the herbaceous, creeping, and ground strata, cover is not an important charac- 
teristic and IV is the sum of relative frequency and relative density. Maximum IV for these strata is 200.

\section{EXPLANATION AND SUMMARY OF PHYSICAL, CHEMICAL, AND BIOLOGICAL DATA}

Physical, chemical, and microbiological data for four wetland habitats in Canaan Valley, West Virginia, are presented in tables 1 to 4 . Habitat locations are shown in figure 1. Data are arranged first by date, with spring, early summer, late summer, and fall sampling trips, then by depth of sediment. Depth of measurement or sample is reported as depth (in centimeters). Depth profiles of $\mathrm{pH}$, oxidation-reduction potential, and temperature are presented for each site. The MPN for denitrifying bacteria and bottom material concentrations of calcium, magnesium, sodium, potassium, nitrite and nitrate nitrogen, ammonia nitrogen, ammonia plus organic nitrogen, phosphorus, inorganic carbon, and total carbon for the top $10 \mathrm{~cm}$ of wetland sediments are also presented for each visit to a site. Plant-community data, consisting of IV and frequency of dominant species in the shrub, herbaceous, creeping, and ground strata, are presented in table 5 .

Additionally, graphs plotting selected characteristics and time are presented in figures 3 a-e. Data for $\mathrm{pH}$, bottom material concentrations of organic carbon, organic nitrogen, and ammonia nitrogen, and the MPN of denitrifying bacteria were plotted for each of the wetland habitats. Figure 3 a shows $\mathrm{pH}$ measured at 3 to $5 \mathrm{~cm}$ below the sediment surface. The concentrations in bottom material of organic carbon as grams per kilogram of carbon are shown in figure $3 \mathrm{~b}$. Bottom-material concentrations of organic nitrogen and ammonia nitrogen in milligrams per kilogram, as nitrogen, are shown in figures $3 \mathrm{c}$ and $3 \mathrm{~d}$, respectively. Figure $3 e$ shows the MPN of denitrifying bacteria per gram of wet soil.

The moss-lichen wetland was characterized by low pH (3.4 to 5.0), small populations of denitrifying bacteria (70 to 400 per gram of wet soil), and was dominated by sedges with a moss ground cover. The scrub-shrub wetland was also acidic (pH 4.0 to 5.0), but supported larger numbers of denitrifying bacteria ( 510 to 11,000 per gram of wet soil). This area was dominated by speckled alder (Alnus rugosa) and a moss ground cover.The number of denitrifying bacteria in the persistentemergent wetland exceeded $1,000,000$ per gram of wet soil in the early summer; $\mathrm{pH}$ in this habitat was higher (5.1 to 6.6) than in the bogs. This area was dominated by spiraea shrubs and bluejoint grass (Calamagrostis canadensis). In the riverine wetland, $\mathrm{pH}$ ranged from 5.4 to 6.9 and the number of denitrifying bacteria ranged from 200 to 11,000 per gram of wet soil.

The data presented in this report were collected during 1992 as part of a project designed to identify microenvironmental determinants of denitrification in Canaan Valley, W. Va. Physical, chemical, and biological characteristics of four wetland habitats were determined by a combination of field measurements and laboratory analyses. Sampling began in March 1992, and data collected at that time were used to develop a sampling protocol for the rest of the study. Sampling trips using these protocols were conducted during June, August, and October. During each trip, samples were collected from four wetland habitats--a moss-lichen wetland, a persistent emergent wetland, a scrub-shrub wetland, and a riverine wetland. Sediment $\mathrm{pH}$, temperature, and oxidation-reduction potential were measured in the field. The most probable number of denitrifying bacteria was determined by multiple-tube tests. Plant communities were analyzed to identify dominant plant species in the moss-lichen, persistent emergent, and scrub-shrub wetlands.

Sediment concentrations of calcium, sodium, magnesium, potassium, nitrate and nitrite, ammonia, ammonia plus organic nitrogen, phosphorus, inorganic carbon, and total carbon were analyzed by the NWQL. 

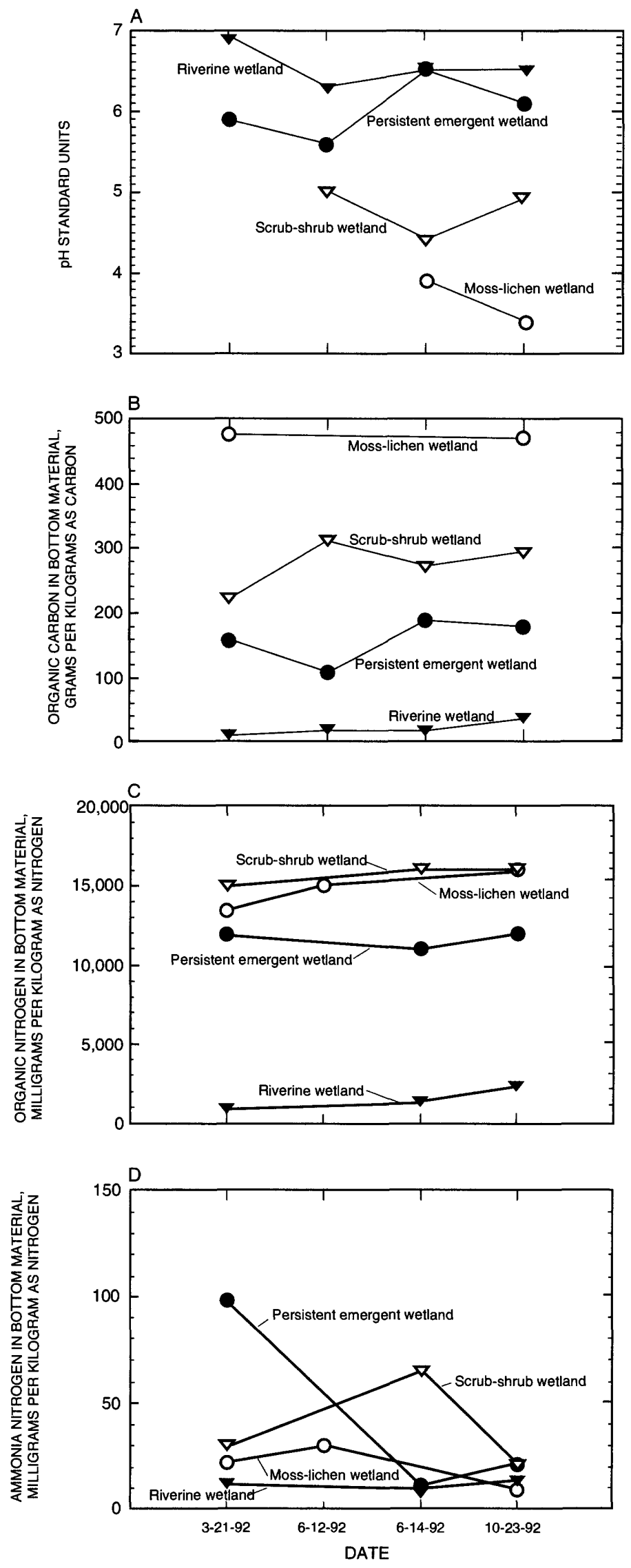

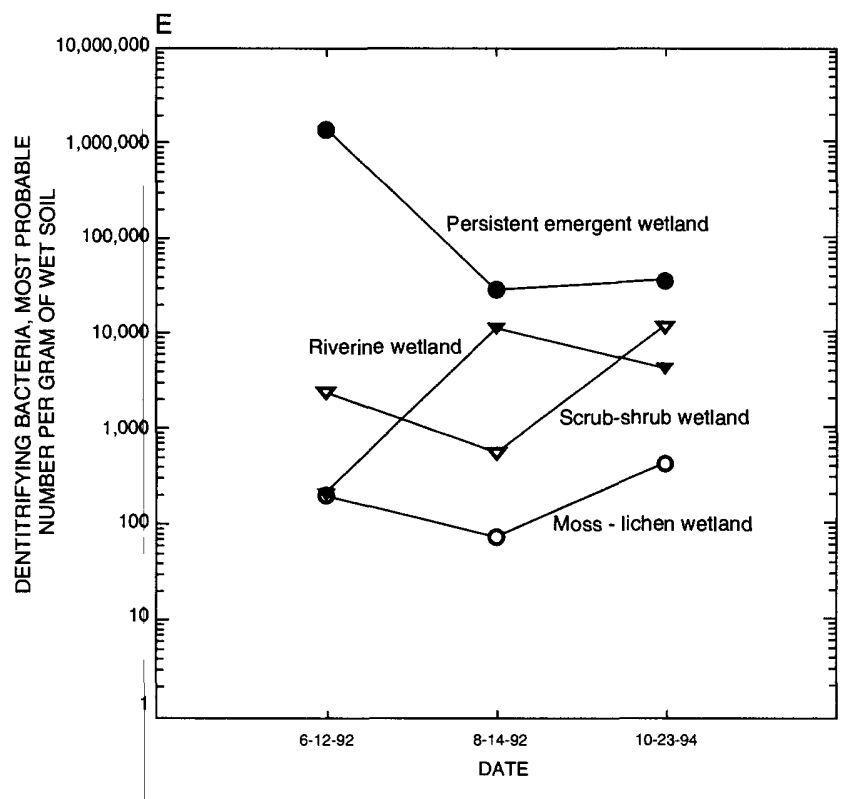

Figure 3. Selected characteristics of four wetland habitats in Canaan Valley (A) $\mathrm{pH} 3$ to $5 \mathrm{~cm}$ below sediment surface (B) organic Carbon in Bottom material (C) organic nitrogen in bottom material (D) ammonia nitrogen in bottom material (E) most probable number of denitrifying bacteria per gram of wet soil, March - October 1992. 


\section{REFERENCES CITED}

American Public Health Association, American Water Works Association, and Water Pollution Control Association, 1989, Standard methods for the examination of water and wastewater, 17 th ed.: Washington, D. C. [about 1450] p.

Barbour, M.G., Burk, J.H., and Pitts, W.D., 1987, Terrestrial plant ecology ( $2 \mathrm{~d}$ ed.): Menlo Park, Calif., Benjamin/Cummings Publishing Company, Inc., 634 p.

Bartlett, M.S., Brown, L.C., Hanes, N.B., and Nickerson, H.N., 1979, Denitrification in freshwater wetland soil: Journal of Environmental Quality, v. 8, p. 460-467.

Bremner, J.M., and Shaw, K., 1958, Denitrification in soil--II. Factors affecting denitrification: Journal of Agricultural Science. v. 51, p. 40-51.

Britton, L.J., and Greeson, P.E., eds., 1989, Methods for collection and analysis of aquatic biological and microbiological samples: U.S. Geological Survey Techniques of Water-Resources Investigations, book 5, chap. A4, 363 p.

Broadbent, F.E., and Clark, F.E., 1965, Denitrification, in Bartholomew, W.V. and Clark, F. E. eds., Soil nitrogen: Agronomy v. $10, \mathrm{p} 344$.

Cameron, C.C., 1970, Peat resources of the unglaciated uplands along the Allegheny structural front in West Virginia, Maryland, and Pennsylvania, chap D of Geological Survey Research: U.S. Geological Survey Professional Paper 700-D, p. D153-D161.

Chen, R.L., Keeney, D.R., Graetz, D.A., and Holding, A.J., 1972, Denitrification and nitrate reduction in Wisconsin lake sediments: Journal of Environmental Quality. v. 1, p. 158-166.
Fortney, R.H., 1975, A vegetational survey of Canaan Valley, West Virginian taxonomic and ecological study: West Virginia University, Morgantown, W. Va., Ph. D. Dissertation

Howes, B.L., Howarth, R.W., Teal, J.M., and Valiela, I., 1981, Oxidation-reduction potentials in a salt-marsh--Spatial patterns and interactions with primary production: Limnology and Oceanography, v. 26, p. 350360 .

Hydrolab, 1991, H20 multiparameter water quality data transmitter operating manual: Austin, Texas, Hydrolab Corporation, p. 28-30.

Jewell, W.J., 1994, Resource-recovery wastewater treatment: American Scientist, v. 82, no. 4., p. $366-376$

Keeney, D.R., Chen, R.L., and Graetz, D.A., 1971, Importance of denitrification and nitrate reduction in sediments to the nitrogen budget of lakes: Nature, v. 233, p. 66-67.

Michaels, E.D., and Pauley, T.K., 1988, Environmental Impact Assessment--Canaan Valley State Park Proposed Expansion: West Virginia Dept. of Commerce, Division of Parks and Recreation, Charleston, W. Va., $129 \mathrm{p}$.

Mitsch, W.J., and Gosselink, J.G., 1986, Wetlands: New York, Van Nostrand Reinhold, 539 p.

Patrick, W.H., and Reddy, K.R., 1976, Nitrification-denitrification reactions in flooded soils and sediments--Dependence on oxygen supply and ammonium diffusion: Journal of Environmental Quality, v. 5, p. $469-472$.

Reddy, K.R., and Graetz, D.A., 1988, Carbon and nitrogen dynamics in wetland soils, in Hooks, D. D., and others (eds.), The ecology and management of wetlands--Vol. 1, Ecology of wetlands: Portland, Oreg., Timber Press, p. 307-318. 
Skougstad, M.W., Fishman, M.J., Friedman, L.C., Erdmann, D.E., and Duncan, S.S., eds., 1979, Methods for determination of inorganic substances in water and fluvial sediments: U.S. Geological Survey Techniques of Water-Resources Investigations, book 5, chap. A1, 626 p.

Smith, R.L. 1990, Ecology and field biology, (3d ed.): New York, Harper and Row, 835 p.

Tchobanoglous, George, and Schroeder, E.D., 1985, Water Quality: Addison-Wesley Publishing Company, Incorporated, Reading, MA. 768 p.

Wiljer, J., and Delwiche, C.C., 1954, Investigations on the denitrifying process in soil: Plant Soil, v. 5, p. 155-162.

Workman, R., 1988, West Virginia Wetlands Conservation Plan: Charleston, W. Va., West Virginia Department of Natural Resources, Wildlife Resources Division, 22 p. 


\section{Tables 1-5}




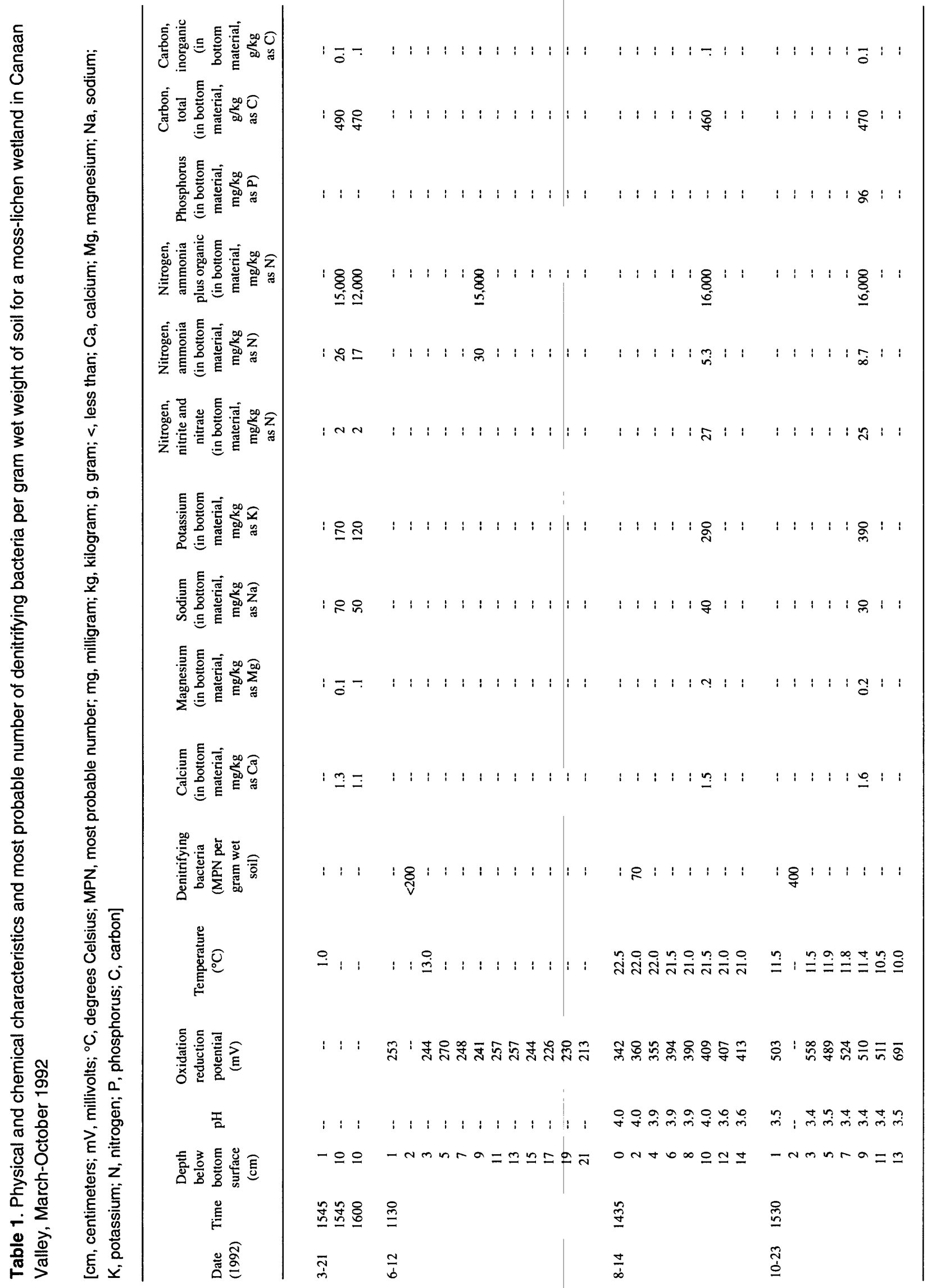




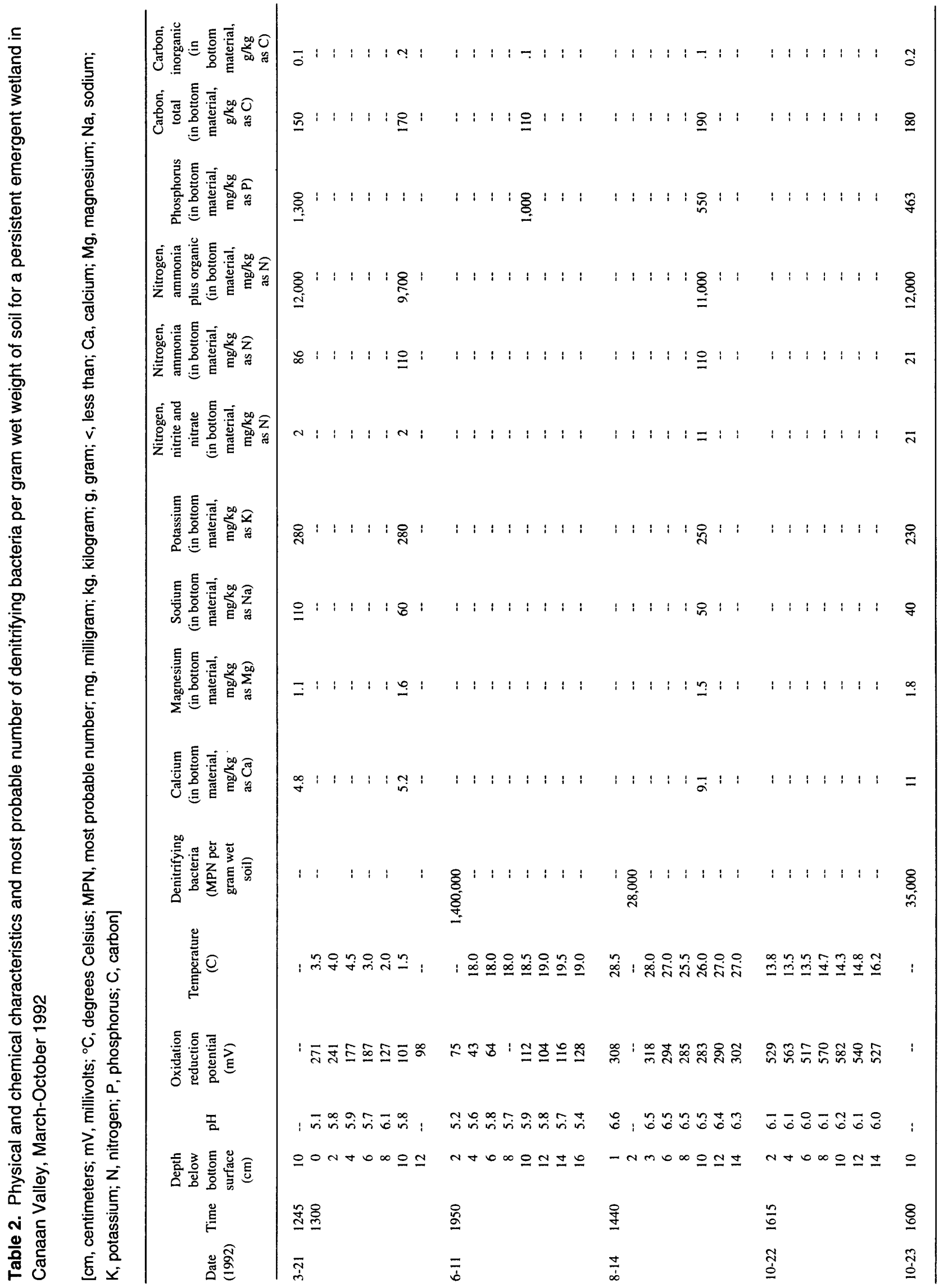




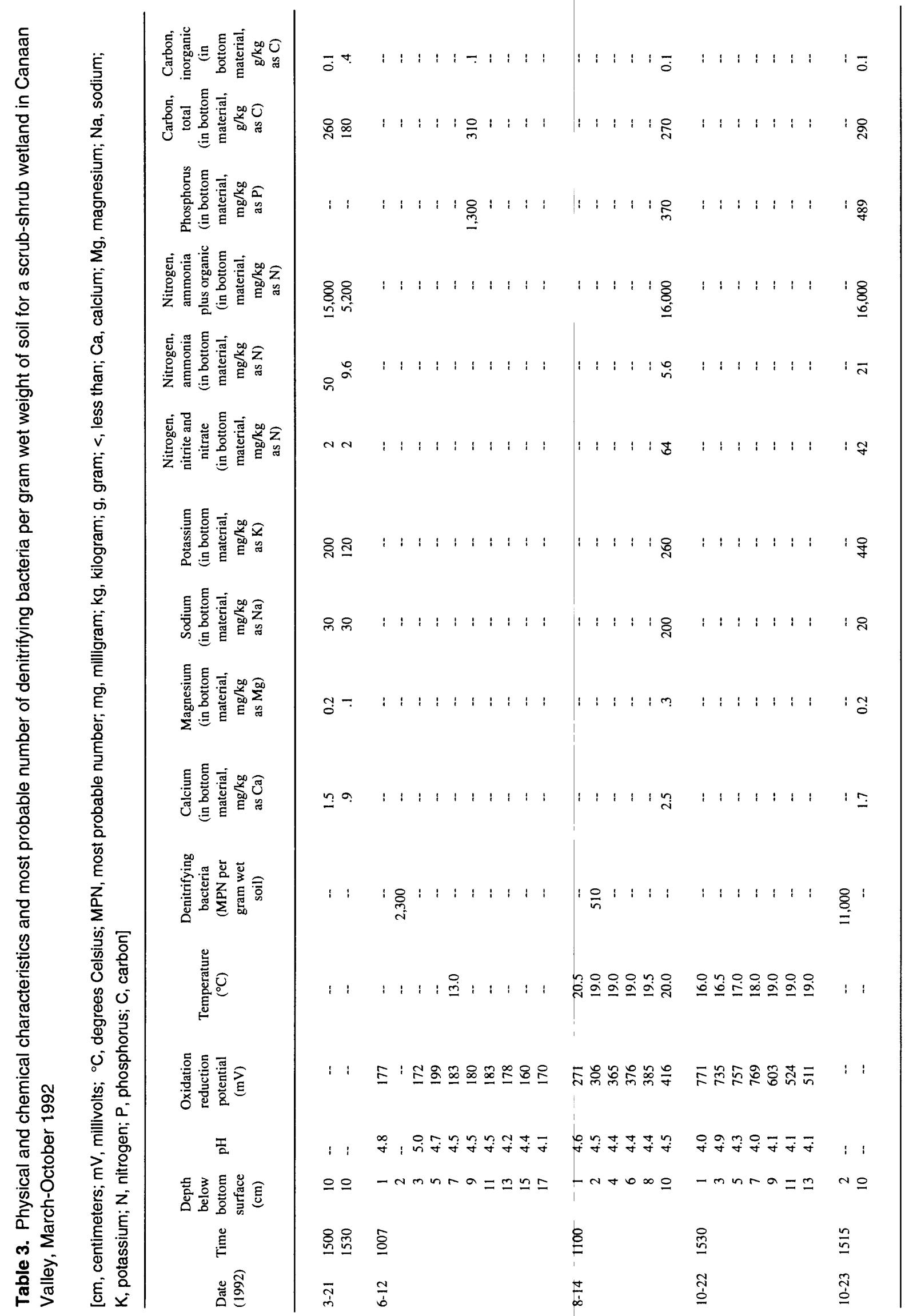




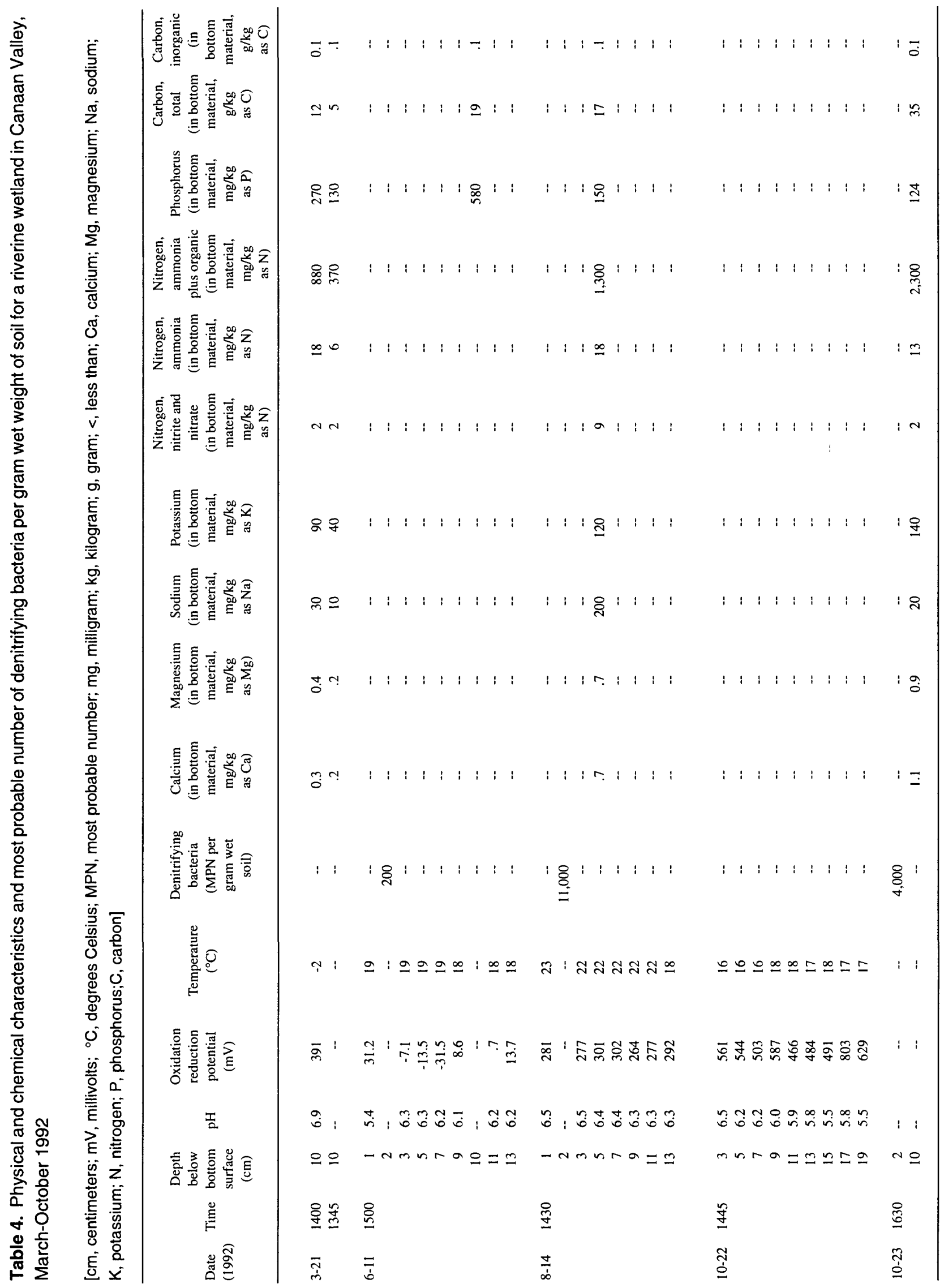




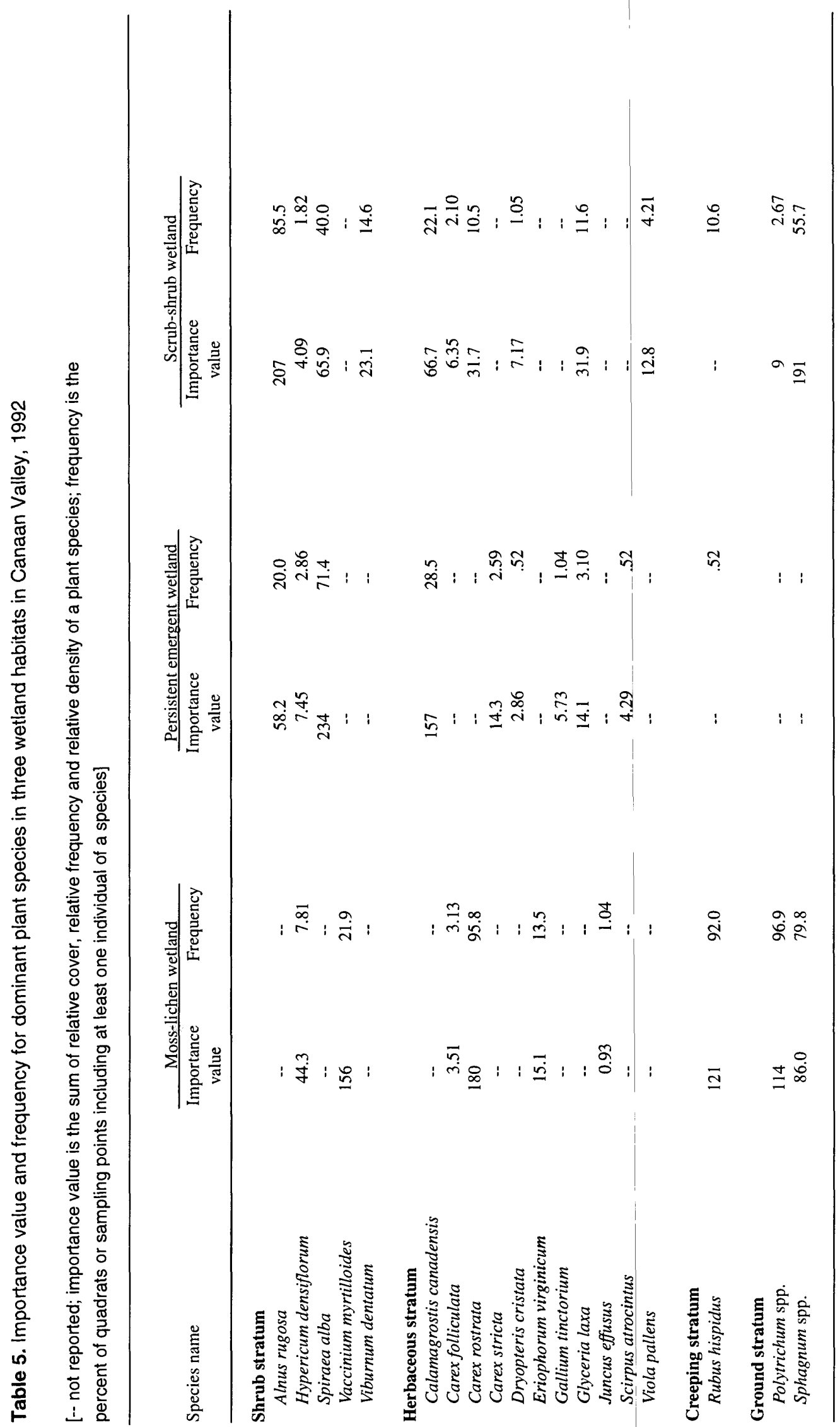




\begin{tabular}{|c|c|c|}
\hline Multiply & By & To obtain \\
\hline $\begin{array}{l}\text { inch (in.) } \\
\text { inch (in.) } \\
\text { foot (ft) } \\
\text { mile (mi) } \\
\text { square mile }\left(\mathrm{mi}^{2}\right) \\
\text { ounce (oz) } \\
\text { ounce (oz) } \\
\text { square foot }\left(\mathrm{ft}^{2}\right)\end{array}$ & $\begin{array}{c}25.4 \\
2.54 \\
0.3048 \\
1.609 \\
2.590 \\
31.1 \\
3,110 \\
0.00929\end{array}$ & $\begin{array}{l}\text { millimeter }(\mathrm{mm}) \\
\text { centimeter }(\mathrm{cm}) \\
\text { meter }(\mathrm{m}) \\
\text { kilometer }(\mathrm{km}) \\
\text { square kilometer }\left(\mathrm{km}^{2}\right) \\
\text { gram }(\mathrm{g}) \\
\text { milligram }(\mathrm{mg}) \\
\text { square meter }\left(\mathrm{m}^{2}\right)\end{array}$ \\
\hline Multiply & By & To obtain \\
\hline $\begin{array}{l}\text { millimeter }(\mathrm{mm}) \\
\text { centimeter }(\mathrm{cm}) \\
\text { meter }(\mathrm{m}) \\
\text { kilometer }(\mathrm{km}) \\
\text { square kilometer }\left(\mathrm{km}^{2}\right) \\
\text { gram }(\mathrm{g}) \\
\text { milligram }(\mathrm{mg}) \\
\text { square meter }\left(\mathrm{m}^{2}\right)\end{array}$ & $\begin{array}{l}0.03937 \\
0.3937 \\
3.281 \\
0.6214 \\
0.3861 \\
0.03528 \\
0.00003528 \\
10.76\end{array}$ & $\begin{array}{l}\text { inch (in.) } \\
\text { inch (in.) } \\
\text { foot (ft) } \\
\text { mile }(\mathrm{mi}) \\
\text { square mile }\left(\mathrm{mi}^{2}\right) \\
\text { ounce (oz) } \\
\text { ounce (oz) } \\
\text { square foot }\left(\mathrm{ft}^{2}\right)\end{array}$ \\
\hline
\end{tabular}

Sea level: In this report, "sea level" refers to the National Geodetic Vertical Datum of 1929--a geodetic datum derived from a general adjustment of the first-order level nets of the United States and Canada, formerly called Sea Level Datum of 1929.

Abbreviated water-quality units used in this report: Chemical concentrations and water temperature are given in metric units. Chemical concentration is given in grams per liter $(\mathrm{g} / \mathrm{L})$, milligram per liter $(\mathrm{mg} / \mathrm{L})$ or micrograms per liter $(\mu \mathrm{g} / \mathrm{L})$. Milligrams per liter is a unit expressing the concentration of chemical constituents in solution as weight (milligrams) of solute per volume (liter) of water. One thousand milligrams per liter is equivalent to one gram per liter. One thousand micrograms is equivalent to one milligram per liter. For concentrations less than $7,000 \mathrm{mg} / \mathrm{L}$, the numerical value is the same as for concentrations in parts per million. 